\title{
Dyslipidemia Increases the Risks For Cerebro Vascular Accident: A Case-Control Study in Panti Nirmala Hospital, Malang
}

\author{
Rea Ariyanti ${ }^{1 *}$, Cecilia Widijati Imam² \\ ${ }^{1}$ Health Management Information Department, STIKEs Panti Waluya, Malang \\ ${ }^{2}$ Health Management Information Department, STIKEs Panti Waluya, Malang \\ *ariantirea@gmail.com
}

\begin{abstract}
Cerebro Vascular Accident (CVA) is one of the major causes of morbidity and mortality in the worldwide. Globally in 2013, stroke was the highest cause of death after heart disease and was the number three cause of long-term disability. Indonesia ranks fourth in the world after India, China and the United States and has the highest proportion of stroke sufferers in Asia.This study aims to determine the relationship of dyslipidemia and cerebro vascular accident in the Panti Nirmala Hospital. Research design is case controll study. The sample amounted to 84 respondents, consisting of 42 case groups and 42 control groups. Data analysis using logistic regression analysis. The finding shows, in patients with CVA, the percentage of respondents with dyslipidemia is $59,5 \%$, while non-CHD is $21,4 \%$. After controlled by a family history of CVA, Smokers, Hypertension or a history of Hypertension, and Hyperirucemia, respondents with dyslipidemia were 5.9 times more likely to have CVA than non-dyslipidemic respondents.It is recommended to the public to carry out regular medical checkup, and changing lifestyles by consuming healthy foods to control lipid profiles.
\end{abstract}

Keywords: Cerebro Vascular Accident, Dyslipidemia, Non Communicable Disease

\section{INTRODUCTION}

Cerebro Vascular Accident (CVA) is one of the non-communicable diseases that has increased. Stroke is an emergency and requires immediate help. Globally in 2013, stroke was the highest cause of death after heart disease and was the number three cause of long-term disability. Longterm disability due to stroke is basically different in each country, but the biggest is in developing countries, one of which is Indonesia. ${ }^{1}$ Indonesia ranks fourth in the world after India, China and the United States and has the highest proportion of stroke sufferers in Asia. In Asian countries, especially Indonesia, an estimated 500,000 people experience strokes every year, of which $2.5 \%$ have died and the rest have severe and mild disabilities. ${ }^{2}$

The problem of CVA is more important because the number of CVA in Indonesia is the highest in Asian countries. CVA can occur to anyone and at any age, but the most likely is happening to people over 60 years of age. ${ }^{3}$ Many factors are thought to be the cause of CVA including factors that can be modified and can not be modified. One factor that can be modified is dyslipidemia. Dyslipidemia is thought to be a primary risk factor for CHD and may play a role before other 
risk factors appear. Dyslipidemia is thought to be a risk factor for CVA because it is associated with atherosclerosis. Dyslipidemia is defined as a lipid metabolic disorder characterized by an increase or decrease in lipid fraction in plasma. The major lipid fraction disorders are increased total cholesterol (K-total), LDL cholesterol (K-LDL), triglycerides (TG), and decreased HDL cholesterol (K-HDL). High cholesterol and triglyceride levels last long can cause thickening of blood vessels with the risk of narrowing of blood vessels. ${ }^{4}$

Dyslipidemia in Indonesia currently has a high prevalence rate. The incidence of dyslipidemia according to MONICA research (Monitoring Trends and Determinants of Cardiovascular Disease) I was $13.4 \%$ for women and $11.4 \%$ for men. In MONICA II (1994) an increase of $16.2 \%$ was obtained for women and $14 \%$ in men. While the prevalence of dyslipidemia based on the 2007 Biomedical Riskesdas Report in Indonesia is $39.8 \%$ when viewed from total cholesterol levels > $200 \mathrm{mg} / \mathrm{dl}$. While based on the 2013 RISKESDAS there are $35.9 \%$ of Indonesia's population who have participated $\geq 15$ years with abnormal cholesterol levels (based on NCEP ATP III, with cholesterol levels $\geq 200 \mathrm{mg} / \mathrm{dl}$ ) where more men and women outnumber Rural. RISKESDAS data also shows a very high proportion of LDL ( $\geq 190 \mathrm{mg} / \mathrm{dl})$, having HDL levels less than $40 \mathrm{mg} / \mathrm{dl}$ of $22.9 \%$, and $11.9 \%$ with very high triglyceride levels $(\geq 500 \mathrm{mg} / \mathrm{dl}){ }^{5}$

Panti Nirmala Hospital is one of the type B hospital in Malang. Based on data from Panti Nirmala Hospital, it is known that the incidence of stroke in the Panti Nirmala Hospital has increased every year. This study aims to determine the relationship between dyslipidemia and the incidence of cerebro vascular accident at Panti Nirmala Hospital.

\section{MATERIAL AND METHOD}

This study used case-controll design with secondary data that is medical record data obtained from Panti Nirmala Hospital. Dependent variable in this research is Cerebro Vascular Acute with the main independent variable is dyslipidemia and confounder potential variable consist of gender, family history of CHD, smoking habit, hypertension or hypertension history, diabetes or diabetes history, obesity, and hiperurisemia or hiperurisemia history.

The population in this study were all patients at Panti Nirmala Hospital. The sample in this study was control cases visited in January 2019 - December 2019 at Panti Nirmala Hospital consisted of 84 respondents. Case criteria were patients diagnosed with CVA consisted of 42 respondents, and the control group was a patient diagnosed with Atrial Fibrilation and Flutter (AFF) consisted of 42 respondents.

Data analyzed with statistic program multivariate analysis with logistic regression where interaction and confounding test were conducted. Interaction assessment is done by inserting interaction variables into complete modeling based on stratification test results. Variables are 
said to interact if they have p-value $<0.05$. Assessment of confounder is done by removing candidate variable confounder one by one starting from variable having highest Wald $p$ value. If the variable after discharging causes the OR variable change of dyslipidemia greater than $10 \%$ then the variable is expressed as confounder and must remain within the model.

\section{RESULTS AND DISCUSSION}

Table 1. The Relationship of dyslipidemia and Covariate with CVA.

\begin{tabular}{|c|c|c|c|c|c|}
\hline \multicolumn{2}{|c|}{ Variable } & $\begin{array}{c}\text { Controll } \\
(\%)\end{array}$ & Case (\%) & OR & $95 \% \mathrm{CI}$ \\
\hline Dyslipidemia & $\begin{array}{l}\text { - No Dyslipidemia } \\
\text { - Dyslipidemia }\end{array}$ & $\begin{array}{c}78,6 \\
21,4\end{array}$ & $\begin{array}{l}40,5 \\
59,5\end{array}$ & 5,4 & $\begin{array}{l}1,8- \\
15,4\end{array}$ \\
\hline Sex & $\begin{array}{l}\text { - Female } \\
\text { - Male }\end{array}$ & $\begin{array}{l}61,9 \\
38,1\end{array}$ & $\begin{array}{l}59,5 \\
40,5\end{array}$ & 1,1 & $0,5-2,7$ \\
\hline $\begin{array}{l}\text { Familiy History of } \\
\text { CVA }\end{array}$ & $\begin{array}{l}\text { - Not have Family } \\
\text { - History } \\
\text { - Have Family History }\end{array}$ & $\begin{array}{l}81,0 \\
19,1\end{array}$ & $\begin{array}{l}73,8 \\
26,2\end{array}$ & 1,5 & $0,5-4,3$ \\
\hline Smoking Habit & $\begin{array}{l}\text { - No Smoking } \\
\text { - Smoking }\end{array}$ & $\begin{array}{l}73,8 \\
26,2\end{array}$ & $\begin{array}{l}47,6 \\
52,4\end{array}$ & 3,1 & $1,2-8,1$ \\
\hline Hypertension & $\begin{array}{l}\text { - No Hypertension } \\
\text { - Hypertension }\end{array}$ & $\begin{array}{r}90,5 \\
9,5\end{array}$ & $\begin{array}{l}66,7 \\
33,3\end{array}$ & 4,8 & $\begin{array}{l}1,3- \\
17,0\end{array}$ \\
\hline Diabetes & $\begin{array}{l}\text { - } \text { No DM } \\
\text { - DM }\end{array}$ & $\begin{array}{l}71,4 \\
28,6\end{array}$ & $\begin{array}{l}54,8 \\
45,2\end{array}$ & 2,1 & $0,9-5,2$ \\
\hline Body Max Index & $\begin{array}{l}\text { - No Obesity } \\
\text { - Obesity }\end{array}$ & $\begin{array}{l}71,4 \\
28,6\end{array}$ & $\begin{array}{l}61,9 \\
38,1\end{array}$ & 1,5 & $0,6-3,9$ \\
\hline Hyperirucemia & $\begin{array}{l}\text { - No Hyperirucemia } \\
\text { - Hyperirucemia }\end{array}$ & $\begin{array}{l}59,5 \\
40,5\end{array}$ & $\begin{array}{l}54,8 \\
45,2\end{array}$ & 1,2 & $0,5-2,9$ \\
\hline
\end{tabular}

The results showed that the percentage of respondents with CVA majority suffer from dyslipidemia (59.5\%), female (59.5\%), did not have family history of CVA (73.8\%), have smoking habit (52.4\%), did not have hypertension or hypertension history (66.7\%), did not have diabetes or a diabetes history (54.8\%), not obesity (61.9\%), and did not have hyperirucemia $(54.8 \%)$.

The results of the analysis of dyslipidemia relationship with CVA showed that respondents with dyslipidemia dyslipidemia were 5.4 times more likely to have CVA than respondents who had not dyslipidemia. Male respondents were 1.1 times more likely to have CVA than female respondents. Respondents who had a family history of CVA were 1.5 times times more likely to have CVA than respondents who did not have a family history of CVA. Respondents who have a smoking habit were 3.1 times more likely to have CVA respondents who do not have a smoking habit. Respondents who have hypertensive or hypertension history were 4.8 times more likely to have CVA than respondents who are not hypertensive. Respondents with diabetes or a history of 
Received : 2020-05-10 Revised : 2020-10-12

Acceptance : 2020-11-23 Publish : 2020-12-07

diabetes were 2.1 times more likely to have CVA than non-diabetic respondents. Respondents with obesity were 1.5 times more likely to have CVA than not obesity. Respondents with hyperirucemia were 1.2 times more likely to have CVA than respondents who are not hyperirucemia

Furthermore, before the multivariable analysis, first perform stratification tests to determine the effect of a control variable on the main variables of dyslipidemia and CVA.

Table 2. Stratification Analyse Dyslipdemia with Covariate Variable

\begin{tabular}{|c|c|c|c|c|}
\hline \multicolumn{2}{|l|}{ Interaction Variable } & $\begin{array}{c}\text { Test of } \\
\text { Homogeinit } \\
y\end{array}$ & OR & CI 95\% \\
\hline \multicolumn{5}{|l|}{ Dyslipidemia*Sex } \\
\hline - Dyslipidemia & Female & 0,259 & 4,0 & $1,1-15,1$ \\
\hline - Dyslipidemia & Male & & 16,9 & $1,7-78,4$ \\
\hline \multicolumn{5}{|c|}{ Dyslipidemia*Family History of CHD } \\
\hline - Dyslipidemia & No Have History & 0,992 & 5,9 & $1,8-20,2$ \\
\hline - Dyslipidemia & Have History & & 5,8 & $0,4-31,5$ \\
\hline \multicolumn{5}{|c|}{ Dyslipidemia*Smoking Habit } \\
\hline - Dislipidemia & No Smoking & 0,748 & 5,2 & $1,2-23,9$ \\
\hline - Dislipidemia & Smoking & & 3,8 & $0,7-23,0$ \\
\hline \multicolumn{5}{|c|}{ Dyslipidemia*Hypertension } \\
\hline - Dyslipidemia & No Hypertension & 0,696 & 4,3 & $1,3-14,7$ \\
\hline - Dyslipidemia & | Hypertensi & & 7,5 & $0,4-43,9$ \\
\hline \multicolumn{5}{|l|}{ Dyslipidemia*Diabetes } \\
\hline - Dyslipidemia & No diabetes & 0,991 & 5,2 & $1,3-13,5$ \\
\hline - Dyslipidemia & Diabetes & & 5,1 & $0,8-37,7$ \\
\hline \multicolumn{5}{|c|}{ Dyslipidemia*Body Max Index } \\
\hline - Dyslipidemia & No Obesity & 0,218 & 3,8 & $1,1-13,5$ \\
\hline - Dyslipidemia & Obesity & & 18,2 & $1,6-86,8$ \\
\hline \multicolumn{5}{|c|}{ Dyslipidemia*Hyperirucemia } \\
\hline - Dyslipidemia | & | No & 0,238 & & \\
\hline $\begin{array}{l}\text { Hyperirucemia } \\
\text { Dyslipidemia }\end{array}$ & a Hyperiru & & 17,8 & $1,8-81,2$ \\
\hline
\end{tabular}

Table 2 shows the results of stratification analysis of 7 control variables that are estimated to affect the relationship of dyslipidemia with CVA. Based on the results of stratification analysis there are no variables that are proven to hold interactions (homogeneity test $p>0.05$ ). 
Received : 2020-05-10 Revised : 2020-10-12

Acceptance : 2020-11-23 Publish : 2020-12-07

Table 3. Complete model Relationship of Dyslipidemia and CVA

\begin{tabular}{lcccc}
\hline \multicolumn{1}{c}{ Variable } & $\mathrm{B}$ & $\begin{array}{c}\mathrm{p}- \\
\text { value }\end{array}$ & $\begin{array}{c}\mathrm{O} \\
\mathrm{R}\end{array}$ & $\mathrm{CI} 95 \%$ \\
\hline Dyslipidemia & 1,772 & 0,006 & 5,9 & $1,7-$ \\
& & & & 20,6 \\
Male & $-0,653$ & 0,490 & 0,5 & $0,1-3,3$ \\
Have Family History of CVA & 1,271 & 0,070 & 3,6 & $0,9-$ \\
& & & & 14,1 \\
Smoker & 1,274 & 0,323 & 3,6 & $0,3-$ \\
& & & & 44,7 \\
Hypertension & 1,727 & 0,015 & 5,6 & $1,4-$ \\
& & & & 22,7 \\
Diabetes & $-0,649$ & 0,610 & 0,5 & $0,1-6,3$ \\
Obesity & 0,612 & 0,295 & 1,8 & $0,6-5,8$ \\
Hyperirucemia & 1,606 & 0,119 & 5,0 & $0,7-$ \\
& & & & 37,6 \\
\hline
\end{tabular}

Based on stratification tests that have been carried out before conducting multivariable analysis, it is known that there is no interaction between the main variables with confounding variables. So, from the complete modeling (Hierarchically Well Formulated Model) it does not appear that there are variables that interact with one another Next do the assessment of confounding variables by removing candidate confounding variables one by one and calculation of OR changes on the main independent variable, obtained results as in table 4.

Tabel 4. Final Model Relationship of Dyslipidemia and CVA

\begin{tabular}{lccc}
\hline \multicolumn{1}{c}{ Variable } & p-value & OR & $95 \%$ CI OR \\
\hline Dyslipidemia & 0,006 & 5,9 & $1,7-20,6$ \\
Have family History of CVA & 0,070 & 3,6 & $0,9-14,1$ \\
Smoker & 0,323 & 3,6 & $0,3-44,7$ \\
Hypertension/ Hypertension & 0,015 & 5,6 & $1,4-22,7$ \\
listory & & & \\
Hyperirucemia & 0,119 & 5,0 & $0,7-37,6$ \\
\hline
\end{tabular}

Multivariable analysis results showed that there was four confounding variable of dyslipidemia relationship with CVA occurrence including familiy history of CVA, Smoker, Hypertension or Hypertension history, and Hyperirucemia. After controlled by a family history of CVA, Smokers, Hypertension or a history of Hypertension, and Hyperirucemia, respondents with dyslipidemia were 5.9 times more likely to have CVA than non-dyslipidemic respondents.

The results showed that a history of hypertension or hypertension was significantly correlated with the incidence of CVA and was a confounder relationship between dyslipidemia and CVA 
events, whereas a family history of CVA, smokers and Hyperirucemia did not correlate significantly with CVA events but it was a confounder relationship between dyslipidemia and CVA events.

The finding shows, in patients with CVA, the percentage of respondents with dyslipidemia is $59,5 \%$, while non-CVA is $21,4 \%$. The research results of this study are supported with the previous results, in the case group (respondents with CVA) it appears that respondents who suffer from dyslipidemia more than those not dyslipidemia. Dyslipidemia is elevation of plasma cholesterol, triglycerides (TGs), or both, or a low high-density lipoprotein level that contributes to the development of atherosclerosis.

The results showed that there was four confounding variable of dyslipidemia relationship with CVA occurrence including familiy history of CVA, Smoker, hypertension or hypertension history, and hyperirucemia. After controlled by a family history of CVA, Smokers, Hypertension or a history of Hypertension, and Hyperirucemia, respondents with dyslipidemia were 5.9 times more likely to have CVA than non-dyslipidemic respondents. This study was supported with previous studies in which dyslipidemia with high blood pressure (hypertension) interacts in causing CHD.

The risk of CHD in patients with dyslipidemia will increase if dyslipidemia is accompanied by one or more other CHD risk factors. Various studies show that other factors that can cause cardiovascular disease is hypertension. Dyslipidemia and hypertension are important risk factors in cardiovascular disease. If these two factors (dyslipidemia and hypertension) are present together it will accelerate the process of atherosclerosis, thus increasing the risk of CHD. Cholesterol is a risk factor that can be changed from hypertension, so the higher the total cholesterol level, the higher the likelihood of hypertension.

The results of this study indicate that sex has no a significant relationship with the incidence of CVA and is a not confounder of dyslipidemia relationship with CVA events. This study was supported with previous studies in which states that gender does not have a significant realtionship with CVA events. ${ }^{6,7}$ The absence of association between sex and CVA is probably caused by the causes of CVA are multifactorial, not just gender but can be caused by the influence of the other factors. Someone who has one or more risk factors, has a greater likelihood of CVA if the factor is not controlled. ${ }^{8}$ In addition, research conducted by Marlina (2011) states that based on the results between sex and CVA, it is known that women have a higher risk for CVA occur than women. The incidence of CVA in women is also said to increase in postmenopausal age. ${ }^{9}$

The results of this study indicate that family history of CVA has no significant relationship with CVA but is a confounder of dyslipidemia relationship with CVA. The results of this study was 
supported with previous studies in which states that family history of CVA does not have a significant relationship with CVA events, ${ }^{10,11}$ but different from the results of research conducted by Ali et al (2019), which showed that family history of CVA have a significant relationship with CVA. ${ }^{12}$ Family history is thought to be a good predictor of CVA risk because family members most closely represent the unique genomic and environmental interactions that an individual experiences. ${ }^{12}$ The absence of association between family history of CVA and CVA events in the results studies is probably caused by genetic influence of CVA is also inseparable from individual risk factors such as hypertension and dyslipidemia.

The results of this study indicate that smoking status has no significant relationship with CVA events but is a confounder of dyslipidemia relationship with CVA. This study was supported with previous studies in which states that smoking status does not have a significant relationshiop with CVA events. ${ }^{11}$ Stroke-related morbidity stems from the fact that tobacco smoke contains over 4000 different chemicals including heavy metals and other toxins that promote the development of free radicals, inducing vascular endothelial dysfunction and inflammation, ultimately leading to the development and acceleration of the atherosclerotic process. In addition, among its other detrimental effects smoking causes an increase in fibrinogen concentration, a decrease in fibrinolytic activity, an increase in platelet. ${ }^{13}$ The absence of association between smoking status and CVA events is probably caused by related to the number of cigarettes smoked each day and also how long the respondent started smoking. Smoking is also directly related to cholesterol levels in the blood, where smoking can reduce HDL levels and increase LDL levels, so the effect of smoking on CVA does not occur directly, but through an increase in cholesterol levels in the blood.

The results of this study indicate that hypertension or history of hypertension have significant relationship with the incidence of CVA and is a confounder of dyslipidemia relationship with CVA events. This study was supported with the previous studies in which states that hypertension or history of hypertension have a significant relationship with CVA events, hypertension was the most predominant risk factor of CVA. ${ }^{6,14}$ Abnormal blood pressure can also cause damage to endothelial cells in blood vessels which cause injury to the vascular cavity. Vascular lesions or lesions will trigger thrombosis and cause atherosclerosis which makes blood vessels narrow so that blood supply to the brain decreases and causes damage to neuron cells in the central nervous system so that the risk of causing CVA. ${ }^{15}$

The results of this study indicate that diabetes or history of diabetes no have significant relationship with the incidence of CVA and is a not confounder of dyslipidemia relationship with CVA events. The result of this study was supported with the previous studies in which states that daiabetes or history of diabetes no have significant relationship with the incidence of CVA. ${ }^{16,17}$ 
The results of this study indicate that obesity has no significant relationship with the incidence of CVA and is a not confounder of dyslipidemia relationship with CVA events. The result of this study was supported with the previous studies in which states that obesity no have a significant relationship with CVA events. ${ }^{11,18,19}$ Respondents with obesity are indeed at risk for CVA, but this risk does not occur directly. Obesity is a risk factor for hypertension, coronary heart disease, and diabetes mellitus.

The results of this study indicate that hyperirucemia no have significant relationship with the incidence of CVA but is a confounder of dyslipidemia relationship with CVA events. Some studies reported a positive independent relationship between hyperuricemia and CVA whereas others demonstrated that hyperuricemia did not relate significantly to CVA occurrence. ${ }^{20}$ The absence of association between hyperirucemia and CVA is probably caused by the effect of hyperuricemia on CVA does not occur directly, but rather through increased blood pressure.

\section{CONCLUSION}

In CVA group, the percentage of respondents with dyslipidemia is 59,5\%, while non-CVA is $21,4 \%$. After controlled by a family history of CVA, Smokers, Hypertension or a history of Hypertension, and Hyperirucemia, respondents with dyslipidemia were 5.9 times more likely to have CVA than non-dyslipidemic respondents.

It is recommended to the public to carry out regular medical checkup, and changing lifestyles by consuming healthy foods to control lipid. It is expected that health workers should prioritize preventive programs by improving communication, information, and education to the public regarding lifestyles, especially those related to positive changes in behavior to control lipid profile. Can change lifestyles by dieting healthy foods such as reducing saturated fat intake, increasing fiber intake and reducing carbohydrate intake to control lipid profile and perform regular health checks in Posbindu Non Communicable Diseases or Health Service Facilities.

\section{REFERENCES}

1. Feigin VL., Norrving B., Mensah GA (2019). Global Burden of Stroke. Vol 120(3). Circulation Research

2. Laily, Siti Rohmatul (2017). Hubungan Karakteristik Penderita dan Hipertensi dengan Kejadian Stroke Iskemik. Surabaya: Universitas Airlangga

3. Suwanwela, NC. (2014). Stroke Epidemiology in Thailnad. Vol 16(1). Journal of Stroke

4. Nurwahyu. (2012). Penelitian Hubungan Profil Lipid Darah Dengan Obesitas Sentral Pada Pasien Penyakit Jantung Koroner Di Poli Jantung Rsud Dr. Hardjono Ponorogo. Ponorogo: Universitas Muhammadiyah.

5. Kementerian Kesehatan RI. (2013). Laporan Riset Kesehatan Dasar 2013. Badan Penelitian dan Pengembangan Kesehatan: Jakarta 
6. Sofyan, AM., Sihombing, IY., Hamra, Y. (2015). Hubungan Umur, Jenis Kelamin, dan Hipertensi dengan Kejadian Stroke. UHO

7. Teguh, H. (2011). Hubungan Kadar Lipoprotein B dengan Aterosklerosis Arteri Karotis Interna Pada Pasien Pasca Stroke Iskemik. Universitas Diponegoro: Semarang

8. Bethesda Stroke Center (2012). Pengetahuan Sekilas Tentang Stroke. http://www.strokebethesda.com/index2.php?option.com. Diakses tanggal 20 februari 2020

9. Marlina (2011). Pengaruh Latihan Range of Motion Terhadap Peningkatan Kekuatan Otot pada Pasien Stroke Iskemik di Ruang Saraf RSUD Dr.Zainoel Abidin Banda Aceh. Journal

10. Nastiti, Dian. 2012. Gambaran faktor resiko kejadian stroke pada pasien stroke rawat inap di RS krakatau medika tahun 2011. Depok: Universitas Indonesia

11. Khairatunnisa, Sari DM. (2017). Faktor Risiko yang Berhubungan dengan Kejadian Stroke pada Pasien di RSU H. Sahudin Kutacane Kabupaten Aceh Tenggara. Jurnal JUMANTIK; Vol 2(1)

12. Ali, I., Abuissa, M., Alawneh, A., Subeh, O., Abu Sneineh, A., Mousa, S., Deeb, I., \& Rayyan, H. (2019). The Prevalence of Dyslipidemia and Hyperglycemia among Stroke Patients: Preliminary Findings. Stroke research and treatment, 2019, 8194960. https://doi.org/10.1155/2019/8194960

13. Shah, R. S., \& Cole, J. W. (2010). Smoking and stroke: the more you smoke the more you stroke. Expert review of cardiovascular therapy, 8(7), 917-932. https://doi.org/10.1586/erc.10.56

14. El-Hajj, M., Salameh, P., Rachidi, S., et al. (2016). The epidemiology of stroke in the Middle East. Eur Stroke J: 1: 180-198

15. Hafid, M.A (2014) Hubungan Riwayat Hipertensi dengan Kejadian Stroke di RSUP Dr.Wahidin Sudirohusodo Makassar. Jurnal Kesehatan Vol 7(1): pp.234-239

16. Burhanuddin, M., Wahiduddin, Jumriani, (2012). Faktor Risiko Kejadian Stroke pada Dewasa Awal (18-40 tahun). Universitas Hasanudin: Makassar.

17. Alchuriyah S, Wahjuni. (2016). Faktor Risiko Kejadian Stroke Usia Muda Pada Pasien Rumah Sakit Brawijaya Surabaya. Departemen Epidemiologi Fakultas Kesehatan Masyarakat. Universitas Airlangga: Surabaya.

18. Deoke, A., Deoke, S., Saoji, A., \& Hajare, S. (2012). Profile of modifiable and nonmodifiable risk factors in stroke in a rural based tertiary care hospital - a case control study. Global journal of health science, 4(3), 158-163. https://doi.org/10.5539/gjhs.v4n3p158

19. Onwuchekwa, AC., Tobin, C., Babatunde, S. (2014). Prevalence and Risk Factors for Stroke in an Adult Population in a Rural Community in the Niger Delta, South-South Nigeria. Journal of Stroke and Cererbovascular Disease, 23(3), 505-510. https://doi.org/10.1016/j.jstrokecerebrovasdis.2013.04.010

20. Mehrpour, M., Khuzan, M., Najimi, N., Motamed, M. R., \& Fereshtehnejad, S. M. (2012). Serum uric acid level in acute stroke patients. Medical journal of the Islamic Republic of Iran, 26(2), 66-72. 